\title{
PENGEMBANGAN SISTEM PENILAIAN BERBASIS ICT UNTUK MENINGKATKAN PROFESIONALISME GURU MATEMATIKA SMP KURIKULUM 2013
}

\author{
Anies Fuady ${ }^{1}$, Isbadar Nursit ${ }^{2}$ \\ ${ }^{1,2}$ Program Studi Pendidikan Matematika Universitas Islam Malang \\ fuadyanies@gmail.com ${ }^{1}, \underline{\text { isbadarnursit001@gmail.com }}{ }^{2}$
}

\begin{abstract}
Abstrak
Tujuan dari penelitian ini adalah untuk meningkatkan profesionalisme guru dalam bidang penilaian. Dengan dikembangkannya Sistem penilaian berbasis ICT tersebut diharapkan dapat mempermudah kinerja guru dalam memberikan penilaian deskriptif pada setiap keunikan kemampuan siswa yang beragam.Target khusus yang ingin dicapai peneliti dalam pengembangan sistem penelitian ini adalah terciptanya produk penelitian berupa sistem penilaian berbasis ICT yang dapat menginterpretasi nilai siswa yang berupa data kuantitatif menjadi data deskriptif yang mampu menggambarkan setiap keunikan masing-masing siswa. Metode penelitian yang digunakan dalam penelitian ini model 4D. Komponen $4 \mathrm{D}$ terdiri dari 4 tahap yaitu Define (pendifinisian), Design (perancangan), Develop (Pengembangan), dan Disseminate (penyebaran). Berdasarkan analisis hasil validasi ahli Pengembang Penilaian dapat disimpulkan bahwa Sistem Penilaian berbasis ICT yang dikembangkan memenuhi kriteria kevalidan yaitu cukup valid dengan banyak revisi dan persentase akhir 76,1\%. Berdasarkan analisis hasil validasi praktisi memenuhi kriteria kevalidan dengan kategori sangat valid tanpa revisi dan persentase akhir adalah 90.33\%. Berdasarkan hasil analisis validasi user pada 3 Guru Matematika SMP menunjukkan bahwa produk Sistem Penilaian berbasis ICT memiliki kriteria praktis tanpa revisi dengan persentase $82,46 \%$.
\end{abstract}

Kata Kunci : Pengembangan, Sistem Penilaian, Kurikulum 2013, ICT

\section{PENDAHULUAN}

Untuk menghadapi MEA (Masyarakat Ekonomi Asia) Guru - guru di Indonesia harus mengingkatkan proefesionalisme untuk mengimbangi kemajuan jaman. Pada tahun 2007 guru merupakan suatu profesi yang ditandai dengan adanya sertifikasi. Oleh sebab itu, dalam melaksanakan tugas-tugasnya guru harus professional. Profesionalisme guru tidak hanya meliputi profesionalisme dalam mendidik, membimbing, mengajar, dan menilai, tetapi juga 
harus melakukan pengembangan kompetensi secara berkelanjutan yang meliputi pengembangandiri, publikasi ilmiah, dan karya inovatif (Widodo, 2013).

Upaya pemerintah dalam menghadapi MEA adalah dengan menyempurnakan Kurikulum Pendidikan sebagai dasar untuk menjalankan roda pendidikan di Indonesia. Kurikulum yang dimaksud adalah kurikulum 2013 sebagai wujud penyempurnaan kurikulum sebelumnya yaitu kurikulum KTSP.Kurikulum baru ini merupakan bagian dari strategi menghasilkangenerasi emas Indonesia yang diharapkan mampu menjawab tantangan jaman. Guruprofesional menjadi simpul penting bagi keberhasilan implementasi Kurikulum 2013 ini. Penilaian autentik pada kuriklum 2013 yaitu dari yang berfokus pada pengetahuan melalui penilaian output menjadi berbasis kemampuan melalui penilaian proses, portofolio dan penilaian output secara utuh dan menyeluruh (Mulyasa, 2013).

Pada kurikulum 2013 sangat berbeda dengan kurikulum sebelumnya yaitu kurikulum KTSP.Salah satu elemen perubahan Kurikulum 2013 adalah pada standarpenilaian.Standar penilaian pada Kurikulum 2013 menggunakan penilaianautentik. Oleh karena itu, penilaian autentik merupakan penilaian yang esensialterutama pada Kurikulum 2013(Bhakti, 2014).

Bhakti juga mengatakan bahwa meskipun penilaian autentik sesuai untuk menilai kemampuan siswa teutama pada aspek keterampilan, tetapi belum semua guru paham tentang cara melaksanakannya. Menurut Rohmawati (2013) Guru di sekolah sangat memerlukan pendampingan kaena masih banyak guru yang mengalami kesulitancara penilaian dalam kurikulum 2013. Kemdikbud (2014) menyatakan bahwa Pada Kurikulum 2013 pola penilaian rapor siswa yang tidak lagi menggunakan angka, melainkan melalui penilaian otentik dalam bentuk deskriptif.Pola penilaian semacam ini diyakini dapat menilai secara utuh seluruh kompetensi siswa yang meliputi aspek pengetahuan, sikap, dan keterampilan.

Namun salah satu guru Sekolah Dasar Negeri (SDN) Menteng 01 Jakarta, Marmi, mengatakan sistem Kurikulum 2013 sekaligus menuntut kerja guru lebih keras. Salah satunya berkaitan dengan sistem penilaian."Harus ada deskripsinya. Butuh waktu yang lama dan lebih ribet," kata dia kepadaTempo, di SDN Menteng 01 Jakarta, Jumat, 15 Agustus 2014 (Rahayu,2014).Hal ini menyebabkan waktu guru banyak yang tersita untuk menyusun Assessmen. Oleh sebab itu, seorang guru membutuhkan alat bantu untuk membantu guru dalam menyusun penilaian deskriptif yang sesuai dengan kurikulum 2013 yang mampu menggambarkaan setiap keunikan kemampuan siswa yang beragam.

Alat bantu yang sesuai dengan kemampuan guru sebagai seorang praktisi pendidikan adalah berbasis Ms. Excel. Aplikasi tersebut merupakan aplikasi yang sangat familiar dikalangan guru, sehingga diharapkan para guru tidak asing lagi dengan aplikasi tersebut.Program dari Microsoft Office tersebut mampu mengolah angka hasil penilaian yang dilakukan oleh guru serta mampu menjalankan algoritma-algoritma pemrograman Visual Basic Aplication (Ms. Excel Macro-Enable) untuk menghasilkan penilaian deskriptif yang sesuai dengan kurikulum 2013.

Dengan menggunakan alat bantu tersebut diharapkan guru semakin profesional dalam menilai siswa sesuai dengan kurikulum 2013. Guru hanya membutuhkan waktu yang relatif 
singkat untuk membuat deskripsi yang panjang untuk satu siswa. Selain itu, deskripsi tersebut juga bisa dipertanggungjawabkan validitasnya karena berdasarkan penilaian kuantitatif yang biasa guru laksanakan saat menilai siswa berdasarkan kurikulum KTSP. Menurut setiawati (2014) Perkembangan ilmu pengetahuan dan teknologi telah mendorong terciptanya kemudahan-kemudahan dalam mengakses informasi, dan memperkecil waktu yang diperlukan untuk memperoleh pengetahuan tersebut. Kemudahan ini semestinya semakin meminimalisir permasalahan-permasalahan dalam bidang pendidikan, khususnya pendidikan matematika.

\section{METODE}

Produk penelitian dan pengembangan yang dihasilkan melalui tahapan penelitian yang tepat dapat dihasilkan produk yang layak. Untuk itu dipilihlah model penelitian pengembangan 4 D (Four D) yang dikemukakan oleh Thiagarajan, Semmel, dan Semmel (Dalam Trianto, 2011). Komponen 4 D terdiri dari 4 tahap yaitu Define (pendifinisian), Design (perancangan), Develop (Pengembangan), dan Disseminate (penyebaran). Alasan pengembang pemilihan model $4 \mathrm{D}$ adalah model $4 \mathrm{D}$ merupakan model yang sistematis, praktis, dan mudah digunakan untuk mengembangkan sistem penilaian ini, serta model tersebut sesuai digunakan untuk mengembangkan sistem penilaian.

Subyek dalam penelitian ini adalah Validator ahli Pengembang Penilaian, Validator Praktisi, dan Angket Respon Pengguna. Validator ahli Pengembang Penilaian melibatkan seorang dosen jurusan matematika yang ahli dibidang penilaian, Validator Praktisi melibatkan guru yang ahli dibidang TIK yang berhubungan dengan penilaian, sedangkan dan Angket Respon Pengguna melibatkan 3 orang guru bidang studi matematika

Dalam Penelitian ini terdapat dua jenis data yang diperoleh yaitu data kuantitatif, dimana data tersebut merupakan data verbal atau deskriptif yang diperoleh dari pilihan jawaban responden yang berupa pernyataan Setuju atau tidak setuju serta data yang diperoleh dari penarikan kesimpulan setelah melakukan analisis data berupa pernyataan valid atau tidak valid dan juga data yang dikumpulkan dari komentar atau masukan dari validator yang ditulis pada lembar validasi. Selain data kualitatif, pada penelitian ini juga menghasilkan data kuantitatif yang berupa skor penilaian terhadap produk sistem penilaian. data ini diperoleh dari skor angket penilaian dari validator ahli, skor pada angket validasi instrumen, serta skor rata-rata yang diperoleh dari hasil perhitungan analisis data.

Instrumen yang digunakan untuk pengumpulan data adalah angket. angket digunakan untuk menentukan analisis kebutuhan guru, analisis penilaian validator ahli, praktisi, dan pengguna untuk mengukur kevalidan produk yang dikembangkan. Instrumen yang digunakan untuk pengumpulan data dalam pengembangan ini adalah Lembar validasi instrumen meliputi lembar validasi angket kebutuhan guru, angket ahli pengembangan, praktisi, dan pengguna; Angket analisis kebutuhan guru, angket penilaian ahli pengembangan, praktisi, dan angket penilaian pengguna

Data kuantitatif dan data kualitatif akan dianalisis sesuai jenis data yang diperoleh. Data Kuantitatif terdiri dari skor hasil lembar validasi instrumen, angket analisis kebutuhan, dan angket penilaian produk. Rumus yang digunakan untuk menganalisis lembar validasi Instrumen adalah Nilai akhir = Jumlah Skor yang diperoleh. Kriteria Validitas analisis berdasarkan Sugiyono (2014) diinterpretasikan tabel 3.1 berikut. 
Tabel 1. Kriteria Validitas lembar Validasi instrumen

\begin{tabular}{ccl}
\hline Jumlah Skor & Kriteria & \multicolumn{1}{c}{ Keterangan } \\
\hline $43-52$ & Sangat Baik & (Tidak Perlu Revisi) \\
$33-42$ & Baik & (Perlu Direvisi Sebagian) \\
$23-32$ & Kurang Baik & (Revisi Sebagian dan pengkajian ulang \\
$13-22$ & Tidak Baik & (Revisi Total/ diganti) \\
\hline
\end{tabular}

Rumus yang digunakan untuk menganalisis hasil dari lembar analisis kebutuhan guru adalah $P=\frac{\Sigma X}{N} \times 100 \%$

(Sugiyono, 2014) dimana

P : Skor akhir

$\Sigma X \quad$ : Jumlah jawaban tiap opsi dari tiap butir pernyataan

$\mathrm{N}$ : Banyaknya pernyataan

Sedangkan Rumus untuk menganalisis hasil dari angket penilaian para ahli dan pengguna adalah $N K=\frac{\Sigma K_{\mathrm{i}}}{N}$, dimana

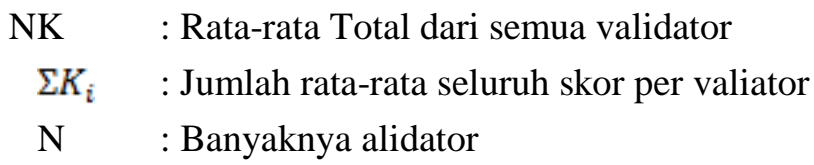

Kriteria untuk menginterpretasi hasil analisis data tersebut ditampilkan tabel 3.2 yang diadaptasi dari Widoyoko (2012) sebagai berikut.

Tabel 2. Kriteria Penilaian lembar Validasi instrumen

\begin{tabular}{ccl}
\hline Rata-rata & Kriteria & \multicolumn{1}{c}{ Keterangan } \\
\hline $3 \leq N K \leq 4$ & Valid & (Tidak Perlu Revisi) \\
$2 \leq N K<3$ & Kurang Valid & (Perlu Direvisi Sebagian) \\
$1 \leq N K<2$ & Tidak Valid & (Revisi Sebagian dan pengkajian ulang \\
& isi/materi) \\
\hline
\end{tabular}

Teknik untuk menganalisis data Kualitatif adalah bahwa Data Kualitatif diperoleh dari komentar, interpretasi data kuantitatif, dan saran dari validator. Ada tiga langkah analisis dalam model ini yaitu Reduksi data, Penyajian data, dan Pengambilan Kesimpulan.

Jika hasil penilaian validator valid maka produk tidak perlu direvisi, kalau kurang valid, maka perlu direvisi sebagian, sedangkan kalau tidak valid, maka harus direvisi total.

\section{HASIL DAN PEMBAHASAN}

Pengembangan dalam penelitian ini menggunakan langkah-langkah model 4-D yang terdiri dari tahap define, design, develop, dan disseminate. Hasil masing-masing tahapan dijelaskan sebagai berikut.

\section{Define}

Pada tahap ini terdiri dari beberapa langkah yaitu analisis ujung depan dan analisis Konsep. langkah-langkah tersebut dijelaskan sebagai berikut

a. Analisis Ujung Depan

Analisis ujung depan diperoleh dengan menyebar angket analisis kebutuhan guru serta mewawancarai langsung guru. Sebelum angket disebar terlebih dahulu angket divalidasi oleh salah satu dosen Pendidikan Matematika dengan hasil yang valid. angket yang valid tersebut diberikan kepada guru Matematika SMP Negeri 1 Batu yaitu Ibu Ida Misaroh dan Guru Matematika SMP 
Negeri 2 Batu yaitu bapak Asmadi. Angket ini terdiri dari 15 butir penyataan yang pilihan jawabannya telah ditentukan

b. Analisis Konsep

Analisis konsep ini merupakan langkah untuk menyusun indikator penilaian pembelajaran sesuai dengan yang diinginkan guru. Misalnya, terdapat penilaian harian yang terdiri dari tugas dan Ulangan Harian, nilai praktek, nilai portofolio, nilaia UTS, dan UAS, serta output nilai dalam bentuk angka, kategoris, maupun deskriptif.

\section{Design}

Pada tahap ini pengembang merancang Sistem Penilaian dengan merancang flowchart dan storyboard terlebih dahulu. setelah itu, merancang sistem penilaian berbasis ICT dalam hal ini adalah Ms. Excel 2010 dan menggunakan VBA (Visual basic for Application). Langkah-langkahnya adalah sebagai berikut.

a. Memprogram Sistem Penilaian Berbasis ICT

Hasil dari program yang telah dirancang pada VBA yang ada di MS. Excel 2010 adalah berupa formula atau rumus pada Ms. Excel yang dapat digunakan seperti rumus pada umumnya pada Ms. Excel. Dari rumus yang telah dirancang terdiri dari rumus untuk mengolah nilai tugas dan nilai Ulangan harian menjadi nilai tugas, mengolah nilai keterampilan, serta mengelola output yang diinginkan seperti angka, nilai kategoris, maupun deskriptif.

b. Mendesain tampilan halaman muka

Ketika rumus telah diprogram, yang perlu dilakukan adalah mendesain halaman antarmuka sistem penilaian yang berbasis Ms. Excel 2010 yaitu memasukkan daftar nomer induk dan daftar nama siswa, kemudian dikolom berikutnya memasukkan nilai pembobotan untuk setiap entri nilai pengetahuan yang terdiri dari nilai harian, UTS, dan UAS serta nilai keterampilan yang terdiri dari nilai praktek, untuk kerja, dan sebagainya. Di kolom berikutnya diisi kolom hasil output penilaian yaitu berupa nilai angka, nilai kategoris, maupun nilai deskriptif.

c. Menyusun Instrumen

Setelah sistem penilaian selesai diprogram, langkah berikutnya yaitu membuat instrumen penilaian yang meliputi:

1. Angket validasi untuk validator ahli penilaian dan validator ahli praktisi serta angket penilaian oleh ahli di bidang pengambangan penilaian dan praktisi.

2. Angket penilaian sistem penilaian untuk subjek validasi terbatas

Pada gambar 1 berikut, ditampilkan desain awal program penilaian deskriptif yang digunakan dalam membantu guru dalam memberikan penilaian deskriptif sesuai dengan karakter siswa tanpa membutuhkan waktu dan tenaga yang sangat banyak sehingga guru dapat meningkatkan profesionalisme dalam bidang penilaian. 


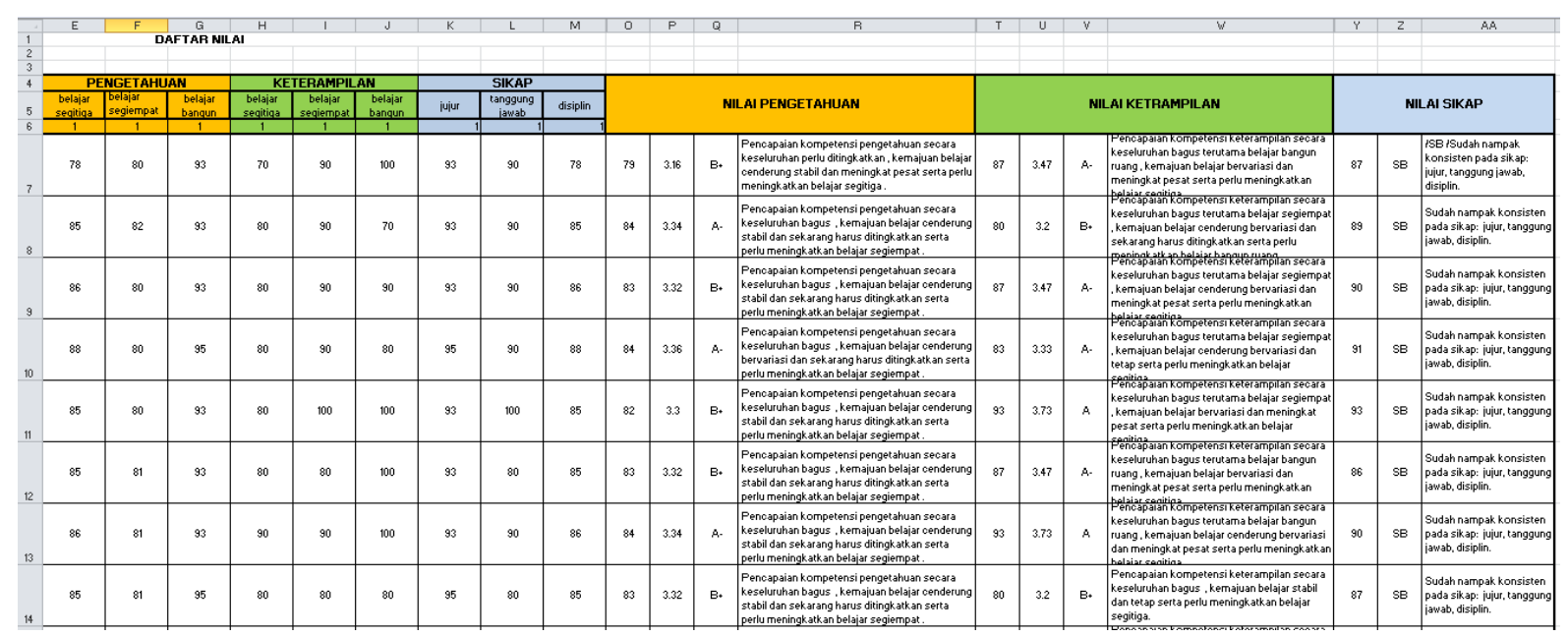

Gambar 1. Desaian awal progam penilaian deskriptif

\section{Develop}

Tahap develop dilakukan dengan memberikan draft Sistem Penilaian berbasis ICT serta instrumen yang telah diperoleh dari tahap design (perancangan) kepada tiga validator untuk divalidasi, tiga validator tersebut yaitu:

\section{Validasi Ahli dan Praktisi}

Draf I Sistem Penilaian yang telah selesai selanjutnya dikonsultasikan kepada Ahli Pengembang Penilaian. Dari hasil konsultasi didapat beberapa saran dan perbaikan. Setelah revisi kemudian dilakukan penilaian oleh validator. Penilaian Sistem dilakukan oleh dua validator yang terdiri dari satu validator ahli penilaian dan satu guru yang berkecimpung dibidang penilaian sebagai praktisi untuk divalidasi. Penilaian bertujuan untuk memperoleh masukan dan mengevaluasi Sistem Penilaian yang disusun. Selanjutnya dilakukan revisi berdasarkan masukan tersebut. Validasi ini juga bertujuan untuk mengetahui layak tidaknya Sistem Penilaian diproduksi dan digunakan di sekolah. Daftar validator dapat dilihat pada Tabel 3. berikut.

Tabel 3 Daftar Validator

\begin{tabular}{lll}
\hline No & Nama & Keterangan \\
\hline 1 & Abdul Halim Fathani, S.Si., M.Pd & Ahli Pengembang Penilaian \\
3 & Arifin Alatas, S.Pd & Praktisi \\
\hline
\end{tabular}

Validator ahli dan praktisi menilai sistem penilaian berdasarkan lembar validasi yang telah dibuat. Sedangkan lembar validasi Sistem Penilaian untuk validator ahli materi dan praktisi tersebut terlebih dahulu divalidasikan kepada validator instrumen.

Setelah angket penilaian LKS untuk validator ahli materi, ahli desain, dan praktisi dinyatakan valid tanpa revisi, selanjutnya dilakukan penilaian oleh validator ahli materi, ahli desain, dan praktisi 2. Validasi Kelompok Kecil

Setelah draf Sistem Penilaian dinyatakan valid oleh ahli penilaian dan praktisi, selanjutnya dilakukan validasi tahap 2 dalam kelompok kecil. Subjek validasi adalah 3 Guru matematika di SMP. Pada validasi ini guru diminta untuk mengamati dan menelaah sistem penilaian yang dikembangkan. Setelah itu, guru diminta untuk mengisi angket penilaian Sistem Penilaian untuk memberi penilaian, komentar, dan saran. Sebelum angket penilaian Sistem Penilaian untuk subjek validasi diberikan kepada subjek validasi, angket tersebut terlebih dahulu divalidasikan kepada validator instrumen untuk mengetahui kelayakan angket tersebut. Setelah angket penilaian untuk subjek validasi terbatas 
dinyatakan valid tanpa revisi, selanjutnya dilakukan validasi. Jawaban dalam angket ini terdiri dari empat pilihan jawaban, yaitu Sangat Setuju (SS) mendapat skor 4, Setuju (S) mendapat skor 3, Kurang Setuju (KS) mendapat skor 2, dan Tidak Setuju (TS) mendapat skor 1.

\section{Disseminate}

Tahap ini merupakan tahap penggunaan Sistem Pnilaian yang telah divalidasi dan diuji cobakan pada skala yang lebih luas dengan tujuan menguji efektivitas penggunaan Sistem Penilaian. Dalam pengembangan ini Penyebarannya melalui media jurnal ilmiah.

\section{Hasil Validasi Produk}

Berdasarkan tabel penyajian data, maka pada bagian ini akan diuraikan hasil analisis dari data-data yang sudah diperoleh dan dijelaskan sebagai berikut.

\section{Hasil Analisis Data Validasi Ahli dan Praktisi}

Analisis data validasi Sistem Penilaian dilakukan dari penilaian ahli penilaian dan praktisi. Setelah diperoleh skor penilaian dari validator, selanjutnya dilakukan analisis data untuk mengetahui kevalidan dari produk. Berikut dipaparkan analisis data uji coba dari tiga validator tersebut.

1. Hasil Analisis Data Validasi Ahli Pengembang Penilaian

Analisis Data Hasil Validasi Ahli Pengembang Penilaian dilakukan dari analisis penilaian ahli terhadap konten dalam Sistem Penilaian. Setelah mendapatkan skor dari ahli, selanjutnya dianalisis per aspek dengan menghitung skor rata-rata tiap aspeknya.

Berdasarkan analisis hasil validasi ahli Pengembang Penilaian dapat disimpulkan bahwa Sistem Penilaian berbasis ICT yang dikembangkan memenuhi kriteria kevalidan yaitu cukup valid dengan banyak revisi dan persentase akhir 76,1\%.

\section{Hasil Analisis Data Validasi Ahli Praktisi}

Selain dinilai oleh ahli, produk juga dinilai oleh praktisi. Praktisi memberikan penilaian produk untuk mengetahui kevalidan dari Sistem Penilaian berbasis ICT, kemudian dianalisis per aspek dengan menghitung persentase skor tiap aspek-aspeknya.

Berdasarkan analisis hasil validasi praktisi, Sistem Penilaian berbasis ICT yang dikembangkan memenuhi kriteria kevalidan dengan kategori sangat valid tanpa revisi dan persentase akhir adalah $90.33 \%$.

\section{Hasil Analisis Data Penilaian Pengguna}

Setelah divalidasi oleh validator ahli dan praktisi, serta memenuhi kriteria kevalidan, maka produk yang dikembangkan dapat divalidasikan kepada pengguna/user. Validasi ini dilakukan untuk mengetahui kepraktisan produk. Dalam pengembangan ini, subjek validasi adalah 3 Guru Matematika SMP.

Berdasarkan hasil analisis validasi user pada 3 Guru Matematika SMP menunjukkan bahwa produk Sistem Penilaian berbasis ICT memiliki kriteria praktis tanpa revisi dengan persentase $82,46 \%$ dapat digunakan pada kelas yang lebih luas.

\section{Revisi produk}

Revisi dilakukan untuk mencapai produk yang sempurna dan memenuhi target ketepatan, kelayakan, dan kegunaan produk. Produk ini melewati beberapa revisi sampai pada hasil akhir yang berupa bahan ajar yang siap digunakan. Berikut adalah paparan hasil revisi produk berdasarkan hasil analisis data uji coba.

1) Data Kualitatif

Berdasarkan hasil validasi serta analisis data dan pembahasan, dapat disimpulkan bahwa produk layak digunakan sebagai bahan ajar yang membantu kegiatan praktikum siswa, namun berdasarkan 
hasil yang kurang maksimal serta komentar dan saran dari validator menunjukkan bahwa terdapat beberapa bagian yang perlu diperbaiki. Berikut akan dipaparkan uraian tentang komentar dan saran dari validator ahli, praktisi, dan user.

a) Data Kualitatif Validasi Ahli

Dalam data kualitatif uji ahli didapatkan komentar dan saran dari ahli materi dan ahli desain pembelajaran yang disajikan pada Tabel 4 .

Tabel 4. Data Kualitatif Validasi Ahli

\begin{tabular}{ll}
\hline \multicolumn{1}{c}{ Ahli } & \multicolumn{1}{c}{ Komentar dan Saran } \\
\hline Ahli & \\
Penilaian & $-\begin{array}{l}\text { Petunjuk penggunaan perlu diperjelas untuk memudahkan } \\
\text { penggunaan }\end{array}$ \\
& $-\begin{array}{l}\text { antisipasi banyaknya tugas atau unsur penilaian sehinga } \\
\text { dapat termuat semua }\end{array}$ \\
\hline
\end{tabular}

b) Data Kualitatif Validasi Praktisi

Dalam data kualitatif validasi praktisi didapatkan komentar dan saran dari guru praktisi yang disajikan pada Tabel 5 berikut.

Tabel 5. Data Kualitatif Telaah Praktisi

\begin{tabular}{ll}
\hline Praktisi & Komentar dan Saran \\
\hline Praktisi & - Kolom untuk nilai harian perlu diperbanyak \\
& - Petunjuk menentukan bobot penilaian \\
\hline
\end{tabular}

c) Data Kualitatif Validasi User

Dalam data kualitatif uji coba user didapatkan komentar dan saran dari 3 guru matematika SMP yang disajikan pada Tabel 6

Tabel 6 Data Kualitatif Validasi User

\begin{tabular}{ll}
\hline Subjek & \multicolumn{1}{c}{ Komentar dan Saran } \\
\hline User 1 & Menjadikan saya semakin sistematis dalam melakuka penilaian \\
User 2 & Sistem penilaian dapat menghemat waktu pengerjaan nilai \\
User 3 & $\begin{array}{l}\text { Sistem Penilaian perlu diberi warna untuk membedakan unsur } \\
\text { penilaian }\end{array}$ \\
\hline
\end{tabular}

2) Tampilan Produk yang Direvisi

Setelah mendapatkan data kualitatif berdasarkan komentar dan saran dari masing-masing validator, selanjutnya dilakukan perbaikan sesuai dengan komentar dan saran dari validator agar produk yang dikembangkan menjadi mendekati sempurna. Uraian revisi yang terjadi adalah pada pengaturan pembobotan nilai, tampilan antarmuka yang sebelumnya minim warna menjadi berwarna untuk membedakan unsur penilaian, serta banyaknya kolom pada penilaian harian

\section{SIMPULAN DAN SARAN}

Sesuai rumusan masalah yang telah ditetapkan pada bagian pendahuluan, maka jawaban dari rumusan masalah dijabarkan sebagai berikut.

1) Proses pengembangan ini dilakukan dengan empat tahap dari model 4-D yaitu: (1) Define (Pendefinisian), meliputi analisis ujung depan dan analisis konsep (2) Design (Perancangan), 
meliputi membuat program Sistem Penilaian, menyusun halaman antar muka sistem penilaian, dan membuat instrumen penelitian; (3) Develop (Pengembangan), meliputi pengembangan Sistem Penilaian berbasis ICT dalam hal ini Ms. Excel 2010 dan VBA untuk guru matematika SMP dan validasi produk oleh beberapa validator yaitu validator ahli pengembangan penilaian dan validator praktisi. Setelah produk dinyatakan valid oleh para ahli dan praktisi, langkah selanjutnya adalah memvalidasikan draf produk kepada user (pengguna) yaitu 3 Guru Matematika di Wilayah batu; (4) Disseminate (Penyebaran), meliputi penyebaran produk pada skala yang lebih luas, yaitu melalui bentuk fisik berupa kepingan $\mathrm{CD}$, maupun media elektronik seperti internat, serta publikasi jurnal ilmiah pendidikan matematika

2) Hasil pengembangan ini adalah Sistem Penilaian berbasis Ms. Excel 2010 dengan pemprograman VBA (Visual Basic for Application) dimana sistem tersebut berjalan pada file extensi .xlsm dengan fitur mengolah nilai harian yang terdiri dari nilai tugas dan nilai ulangan harian, pengolah nilai keterampilan, serta outputnya dapat berupa nilai angka, nilai kategori, serta nilai deskriptif.

3) Validasi produk dalam pengembangan ini dilakukan oleh validator ahli materi, validator ahli desain dan validator praktisi, serta user (pengguna). Penilaian produk oleh validator ahli materi memenuhi kriteria cukup valid dengan persentase $76,1 \%$, penilaian validator praktisi memenuhi kriteria sangat valid dengan persentase $90,33 \%$, dan penilaian produk oleh user (pengguna) memenuhi kriteria valid dengan persentase $82,46 \%$. Dengan menghitung persentase rata-rata dari penilaian ahli, praktisi, dan user (pengguna) maka diperoleh skor 83,34\% yang berarti Sistem Penilain memenuhi kriteria valid dan layak digunakan.

Saran dalam penelitian ini adalah Sistem Penilaian berbasis ICT ini dikembangkan pada mata pelajaran matematika, sebaiknya dikembangkan lebih luas lagi untuk mata pelajaran yang lain atau bidang studi yang lain. Sistem Penilaian berbasis ICT ini berdasarkan basis Ms. Excel 2010, maka untuk meningkatkan kualitas produk, sebaiknya dikembangkan Sistem Penilaian berbasis ICT dengan basis program yang lebih baik. Sistem Penilaian berbasis ICT ini belum diuji keefektifannya jadi untuk para pengembang selanjutnya diharapkan menguji produk sampai keefektifan.

\section{DAFTAR RUJUKAN}

Bhakti, A. 2014. "Pengembangan Model Penilaian Autentik Berbasis kurikulum 2013”. Jurnal OnLine Universitas Negeri Malang, (Online), (http://jurnalonline.um.ac.id/data/artikel/artikel2B5157FBA171A8046A8FBCAD73267BA6.pdf diakses pada 24 April 2015.

Borg, W. R. and Gall, M. D. 1983. Educational Research: An Introduction. 4 Ed.New York: Longman, Inc

Havnes, A and McDowell, L. 2008. Balancing Dilemmas in Assessment and Learning in Contemporary Education. New York: Master eBook.

Kemdikbud. 2014. Kurikulum 2013: Sistem Penilaian Deskriptif Memuat Lengkap Kompetensi Siswa, (Online),(http://litbang.kemdikbud.go.id/index.php/index-berita-kurikulum/652kurikulum-2013-sistem-penilaian-deskriptif-memuat-lengkap-kompetensi-siswa diakses pada 28 Februari 2015).

Kemdikbud. 2014. Paparan Wamendikbud: “Konsep dan Implementasi Kurikulum 2013”. Jakarta: Kementrin Pendidikan dan Kebudayaan.

Meyer. C. 1992. What's Different Between Authentic And Performance Assessment? Educational Leadership.

Mulyasa. 2013. Pengembangan dan Implementasi Kurikulum 2013. Jakarta: Rosda.

Mueller, J. 2014. Authentic Assessment Tool Box, (Online), 
(http://jfmueller.faculty.noctrl.edu/toolbox/index.htm), diakses 9 Februari 2015

Popham, W.J. 2008.Transformative Assessment. USA: ASCD.

Rahayu, D. S. 2014. Guru: Penilaian di Kurikulum 2013 Lebih Ribet, (Online), (http://www.tempo.co/read/news/2014/08/16/079600023/Guru-Penilaian-di-Kurikulum-2013Lebih-Ribet diakses 28 Februari 2015).

Rohmawati. 2013. Kurikulum 2013, 87 Persen Guru Kesulitan Cara Penilaian, (Online), (http://unnes.ac.id/berita/87-persen-guru-kesulitan-soal-penilaian-kurikulum-2013/ diakses 28 Februari2015).

Setiawati, N. 2014. "Kedudukan dan Pemanfaatan Teknologi Informasi dan Komunikasi dalam Pembelajaran Matematika Sebagai Implementasi Kurikulum 2013". Prosiding seminar nasional pendidikan matematika Volume 1, Tahun 2014.ISSN 2355-0473 di ProgramPascasarjana STKIPSiliwangi Bandung.

Sodikin M. 2014. Sistem Penilaian Siswa Kurikulum 2013 Sulitkan Guru.(Online), (http://pendidikan190.blogspot.com/2014/09/sistem-penilaian-siswa-kurikulum-2013.html), diakses pada 28 Februari 2015.

Trianto. 2007. Model Pembelajaran Terpadu dalam Teori dan Praktek. Jakarta: Prestasi Pustaka Publisher.

Sudjana, N. 2014. Penilaian Hasil Proses Belajar Mengajar. Bandung: PT Remaja Rosdakarya.

Widodo. 2013. "Menyongsong Pelaksanaan Kurikulum 2013 Bidang Matematika dan Pendidikan Matematika". Prosiding Seminar nasional matematika dan Pendidikan matematika, Vol 1, Thn. 2013.ISSN 977-2338831di STKIP Siliwangi Bandung. 